\title{
Review of David D. Raphael's The impartial spectator: Adam Smith's moral philosophy. Oxford: Oxford University Press, 2007, 143 pp.
}

\author{
NEVEN LEDDY \\ Simon Fraser University
}

This book is the summation of 40 years of David Raphael's engagement with Adam Smith. The impartial spectator represents a significant development in that engagement, though there is not a great deal of new material in this volume. Raphael's greatest scholarly contributions have often come in his editorial work, beginning in 1948 with his critical edition of Richard Price's Review of the principal questions in morals. His 1976 edition of Adam Smith's Theory of moral sentiments (TMS) included a hugely influential introduction, co-written with his Glasgow University colleague Alexander L. Macfie. The great success of that edition, since taken up by the Liberty Fund (1982), was to demonstrate the importance of reading Smith through the six editions of that work. It is difficult to underestimate the importance of Raphael's approach to Smith's Theory of moral sentiments, which is restated and further developed in this book.

This volume can be most profitably read as Raphael's settling of accounts with the world of Smith scholarship, and an attempt to synthesize his scattered comments on Smith in various articles over the years, with additional reflections on the themes of greatest interest to him. In so doing Raphael touches on many of the central debates in Smith scholarship over the past four decades. As such, this book provides a valuable insight into the reception and interpretation of Adam Smith from the gestation of the Glasgow Edition of his works (1976-1987) through to the present.

Unfortunately, the apparatus of this monograph is a weakness: both the index and the bibliography are slight. Raphael's references to his own edited selections of Hume, Kames, Hutcheson, and Shaftesbury from British moralists (1969) is perhaps understandable, but adds to the impression that his scholarship is less than entirely up to date. In this, Raphael has not lived up to the high standards of his own editorial work. 
Raphael's argument is that in 1759 Smith set himself the task of explaining both moral judgement and the character of virtue. According to Raphael, he not only failed at the second task, but he did not even notice his failure until the 1780 s, and then sought to correct it in the sixth edition in 1790 by adding a new Part VI 'Of the character of virtue'. This new sixth part too, according to Raphael, is a failure-at least in contrast to Smith's success in developing a theory of moral judgement. Raphael's identification of Smith's failings in the discussion of the character of virtue in the 1790 edition dates back to his 1992 essay, which was initially developed in response to criticism of his stoicization thesis by Lawrence Dickey. The stoicization thesis is the straightforward argument that in the final edition of TMS, Smith gave far more attention to the stoic tradition than to any other, which reflected his own increasingly stoic outlook-an interpretation that was challenged by Dickey through the concept of prudence. At the time, Raphael grudgingly acknowledged that there was a problem with his initial presentation of prudence as stoic in 1976, but he ascribed that problem to a mistake on Smith's part. In the present volume he develops on Smith's failure, and obliquely reasserts his view of prudence as essentially stoic, a claim he had abandoned in 1992. His treatment of the impartial spectator as stoic "in context" remains unchanged from 1976. Raphael is equally determined to defend his view of Smith's moral philosophy as a marriage of Christian benevolence and stoic selfcommand, and Smith himself as a sceptical deist.

In the first chapter, he tips his hat to his former student T. D. Campbell (Raphael 2007, 4), retraces his own tracks on certain occasions, and abandons certain claims from the 1976 introduction, all the while retaining his emphasis on working through the editions. Raphael disavows the 1976 claim that the extensive revision to the 1790 sixth edition constitutes a "new book", which he attributes to an exaggeration on the part of Alexander L. Macfie (p. 5). His foremost claim in this chapter is that TMS is a largely descriptive work, in which he follows closely on Campbell, but then further argues that this was not Smith's advertised intent. On this reading, the new material on the character of virtue in Part VI of the sixth edition in 1790 was an attempt to provide a normative theory of virtue.

In the next chapter he offers an interpretation of approval and sympathy in TMS through Hume's comments on the first edition, which is an elaboration of his twice-published piece "Adam Smith and 'the 
infection of David Hume's society'” (1969, 1976). More significantly for current Smith research is his development of 'spontaneous sympathy', distinct from the common reading of Smith's sympathy as an imaginative process. Raphael begins by prioritizing imagination over sympathy in Smith's system, arguing this is not a conscious process:

An explicit exercise of the imagination is certainly part of Smith's account of moral judgment. In that context imagining oneself in someone else's place is more pervasive than the actual experience of sympathy (Raphael 2007, 13).

He goes on to distinguish between approval and sympathy:

The identity view (of approval and sympathy as synonymous) is in any event far-fetched, while the causal connection seems a reasonable account of the psychological explanation that Smith has in mind. I conclude that the two statements of identity are a rhetorical lapse, intended to emphasize the necessity of the connection between sympathy and approval (p. 18).

In effect, Raphael offers a corrected version, not of his own scholarship, but of Smith's. Raphael then explains that Smith's argument was worked out in response to Hume's objection to the first edition of TMS, regarding sympathy with tragedy. In the third chapter Raphael offers an insightful critique of Smith's theory of sympathy with motive and consequence:

We have to conclude that Smith's portrayal of the role of sympathy in judgments of propriety is unduly limited. He represents it as sympathy with motive alone, instead of including also sympathy with intended or probable consequences (p. 25).

This process, where critique is employed as a form of rehabilitation is common to the book as a whole, giving the impression that Raphael is keen to see a corrected Smithian sympathy take its rightful place in contemporary philosophical discourse.

\section{STOICISM AND THE IMPARTIAL SPECTATOR}

Raphael's stoicization thesis has endured over 30 years of sustained fire, and is here deployed in its final streamlined version, having previously been updated in 1992. The Dawes Hicks lecture on philosophy of 1972 is acknowledged as the initial source of chapters 4 
to 6, though Raphael passes over another version published in Essays on Adam Smith (1975), which offered only slight revisions to that initial presentation. This is, in fact, the third published version of that lecture and consequently invites certain tedium on the part of the faithful reader. By the same token, however, it is in the details of the revisions that the significance of this book emerges. If Raphael taught us to interrogate Smith's TMS through the successive editions of this work, the same approach applied to Raphael's work yields some interesting insights into his influential stoic reading of Smith.

Raphael repeats the view that "Humanity and self-command together constitute for Smith 'the perfection of human nature', a combination of Christian and stoic virtue" (p. 34). Likewise, Raphael rolls out the association of the impartial spectator to stoicism and self-command in the context of its introduction: "he first spoke of the 'impartial' spectator when describing the stoic virtue of self-command, which he placed on a par with the Christian virtue of love" (p. 40). In 1992 Raphael had argued that Smith himself was mistaken in this presentation of prudence as incorporating self-command-in 2007, he further suggests that the entire undertaking of the new sixth part of the 1790 edition is a failure, and in so doing he further marginalizes prudence. Moreover, having ceded a certain amount of territory to Dickey on this point in 1992, he here attempts to make the claim in a different way, suggesting that prudence can be reduced to "living according to nature", that is, in the most common definition, living a stoic life.

\section{PSYCHOLOGY AND THEOLOGY}

In the seventh chapter, Raphael returns to the issue of descriptive and normative elements in Smith's system, this time in a theological context:

Is the end result Smith's own view, or is he simply showing how the conventional view (of people generally, reflected in rationalist philosophy) comes about, without implying that he himself shares it? [...] This would mean that Smith is a theoretical sceptic and a pragmatic conformist (p. 53).

Raphael's point is that there is a link between conscience and prudential self-interest, alluded to by Butler, and that this posed three problems for Smith. Of the first, Raphael concludes that: 
He calls prudence a virtue, that is, a possible object of positive moral judgement; but he does not write of prudence as itself a form of moral judgement. I conclude that we must reject as faulty Smith's first philosophical argument for the thesis that moral rules are laws of God (Raphael 2007, 61).

The [second] argument is based on self-interest and assumes that an appeal to this motive is the best, or the most likely, way to induce us to obey the rules of morality. No doubt it is effective for people who are ready to accept the underlying theological doctrine (p. 61).

Smith's third argument is of unintended consequences, which Raphael calls the economic case. He then suggests a paradox where moral sentiments do not line up with the economic case for moral rules:

Both the economic tendencies and the common moral sentiments are products of nature, so that nature is inconsistent. Smith does not seem to be worried about this (p. 62).

Into this inconsistency, Raphael injects Smith's purported theism as a solution, which seems to be an instrumental use of the text. I would suggest instead that there is something of a three dimensional paradox in Smith: that he approaches these problems on different planes of explanation, moving from one to another (from the economic to the psychological in this instance) when it suits his purpose. Raphael's insistence on finding a "solution" to this technique seems to me inappropriate and unnecessary.

This theistic and explicitly anti-materialist reading of Smith is further developed in chapters 8,9 , and 11 . In chapter 8 this takes the form of a marginalization of prudence and an emphasis on a tandem of Christian benevolence and stoic self-command. This interpretation carries over into chapter 9 "The cardinal virtues" where prudence is discussed in economic and political contexts, as inferior and superior prudence respectively - a distinction added in the sixth edition. Raphael further argues "that Smith never was a practical atheist" (p. 79), based on Smith's final position regarding universal benevolence in the sixth edition. Chapter 11 presents a refined claim regarding Smith's religiosity: that Smith gradually abandoned Christianity, but remained a theist. With reference to TMS II.ii.3.12, Raphael explains:

The text of the first edition, in its specific reference to atonement as part of revealed doctrine, implies acceptance of specific Christian 
belief as well as of natural religion. [...] The sixth edition seems to have abandoned it [revealed doctrine] altogether (Raphael 2007, 98).

This amounts to a kind of a process of elimination by which Raphael concludes that Smith was a theist. (The primacy or even the incorporation of prudence in the life of virtue by Smith would have suggested "practical atheism" according to Raphael.) In the face of textual evidence of Smith's waning faith in the divinity of Christ and the Christian worldview, however, Raphael refines his interpretation into mitigated scepticism-and on that point he suggests that Smith was somehow cowed by Hume's ghost (p. 100). In short, Raphael's theistic reading of Smith is predicated on the marginalization of the virtue of prudence in the earlier chapters; the result is that these equally tenuous claims become interdependent.

While I find neither of these interpretations particularly convincing, Raphael's presentation of them as parts of one unified case at the very least makes his argument clear. Previously, in his various writings, it has not always been obvious why he placed such importance on denying the Epicurean flavour of prudence in the teeth of much criticism. His theological presentation of Smith is likewise much more accessible in the present version. As a result, this book will serve as a more effective entry into Smith scholarship than either the introduction to the 1976 Glasgow Edition of the TMS, or any one essay of Raphael's. In this case the whole is certainly more than the sum of its parts, and for that Raphael should be pleased, and Smith scholars grateful.

\section{REFERENCES}

Dickey, Laurence. 1986. Historicizing the 'Adam Smith problem': conceptual, historiographical, and textual issues. Journal of Modern History, 58 (3): 579-609.

Price, Richard. 1948 [1758, 1787]. Review of the principle questions in morals, ed. David Daiches Raphael. Oxford: Clarendon Press.

Raphael, David Daiches. 1969. British moralists 1650-1800. Oxford: Clarendon Press.

Raphael, David Daiches. 1969. Adam Smith and 'the infection of David Hume's society'. Journal of the History of Ideas, 30: 225-248. Reprinted as Appendix II in Adam Smith's The theory of moral sentiments, eds. David D. Raphael, and Alexander L. Macfie. 1976. Oxford: Oxford University Press.

Raphael, David Daiches. 1975. The impartial spectator. In Essays on Adam Smith, eds. Andrew S. Skinner, and Thomas Wilson. Oxford: Clarendon Press, 83-99.

Raphael, David Daiches. 1992. Adam Smith 1790: the man recalled; the philosopher revived. In Adam Smith Reviewed, eds. Peter Jones, and Andrew S. Skinner. Edinburgh: Edinburgh University Press, 93-118. 
Raphael, David Daiches. 2007. The impartial spectator: Adam Smith's moral philosophy. Oxford: Oxford University Press.

Raphael, David Daiches, and Alexander Lyon Macfie. 1976. Introduction to the Glasgow edition of Adam Smith's The theory of moral sentiments, eds. David D. Raphael, and Alexander L. Macfie. Oxford: Oxford University Press, 1-52.

Smith, Adam .1976 [1759]. The theory of moral sentiments, The Glasgow edition of the works and correspondence of Adam Smith, ed. David D. Raphael. and Alexander L. Macfie. Oxford: Oxford University Press.

Smith, Adam .1982 [1759]. The theory of moral sentiments, ed. David D. Raphael. and Alexander L. Macfie. Indianapolis: Liberty Fund.

Neven Leddy teaches in the departments of history and humanities at Simon Fraser University. He is the author of articles on Adam Smith's cultural and intellectual context in the Adam Smith Review and Epicurus in the Enlightenment (Studies on Voltaire and the eighteenth century, SVEC 2009: 12). His current research focuses on Scottish interaction with the Francophone world in Geneva, Paris, and Montreal.

Contact e-mail: <NBLeddy@gmail.com> 